\title{
Spatial Heterogeneity and Cause Analysis of Water Quality of Coastal City River System in Flood and Non-Flood Season: a Case Study of Haikou, China
}

\author{
Haitao Chen, Rui Shi, Wenchuan Wang* \\ Henan Key Laboratory of Water Resources Conservation and Intensive Utilization in the Yellow \\ River Basin, School of Water Resources, North China University of Water Resources and Electric Power, China
}

Received: 13 December 2020

Accepted: 13 May 2021

\begin{abstract}
Through the 26 monitoring sections established in Haikou, 7 water quality indicators were recorded. GIS spatial analysis functions were used to conduct water quality analysis and map water quality variations in Haikou. The results showed that the water quality was worse in non-flood seasons than during flood seasons. The primary pollutant is $\mathrm{NH}_{3}-\mathrm{N}$, whose average value $\left(4.44 \mathrm{mg} \cdot \mathrm{L}^{-1}\right)$ exceeds the Class V water quality standard and has a high variation coefficient (177\%). There are significant spatial differences, which are greatly affected by human activities and the tertiary industry. The primary pollutant in the flood season is TP, with an average value of $0.47 \mathrm{mg} \cdot \mathrm{L}^{-1}$, a strong variation with significant spatial differences. From the perspective of spatial distribution, the overall water quality shows a trend of deterioration from inland to near the sea entrance. The most severe pollution is the $\mathrm{H} 2$ cluster, which is located in the main urban area and where many rivers enter the sea. It is a key area for water pollution prevention and control.
\end{abstract}

Keywords: Haikou, flood and non-flood season, water quality, land use, correlation analysis

\section{Introduction}

Water quality plays a vital role in human activities, the sustainable development of the social economy, and the development and utilization [1-2]. Among them, the water quality of rivers entering the sea and the flux of pollutants transported are among the most critical factors affecting coastal waters' ecological environment

*e-mail: zzlwxz@126.com

[3]. In particular, China's coastal areas' rapid economic development has caused the continuous decline of the water environment quality of many rivers and their estuaries and the bay area. Rivers entering the sea as the most critical land pollution source of marine pollution are receiving widespread attention [4].

Climate, land use, and the loss of nutrients in the soil cause spatial variability in water quality in the basin [5-7]. The intensity of land use types and the different scales from the river bank also significantly affect various water quality indicators in the water body [8]. Besides, studies have shown that the basin's 
social economy also has a specific impact on the water environment's quality [9].

Due to the numerous water quality indicators, different units, and mutual influence [10-11], the comprehensive analysis of water quality is very complicated [12], so robust and straightforward statistical data and methods are needed [13]. Geospatial analysis and correlation analysis provide a reliable method for spatiotemporal identification and analysis of water quality parameters [14-15]. Ahearn et a1. [16] used an optimized linear mixed-effects model to discuss land use's impact on water quality in different hydrological periods and regions. Tran et a1. [17] analyzed the changes in the relationship between LUCC and water quality under other proximity through methods such as principal component analysis, correlation analysis and breakpoint regression. Wang et a1. [7] used cluster analysis and stepwise linear regression model to study land use's effect on water quality under different disturbance gradients. With the rapid development of industrialization and urbanization, the impact of human activities caused the heterogeneity of land use types between basins and the types and levels of social and economic activities carried by the same land-use type. This heterogeneity makes the impact of land use types on water quality very different between different basins so that the contribution rate of land-use types to water quality is reduced [18-20]. Therefore, when analyzing the relationship between land use type and water pollutant concentration, the impact of land use on water quality may become blurred due to socio-economic differences, resulting in deviations between the analysis results and the actual results, thereby reducing the accuracy of the conclusions. It is necessary to comprehensively consider the impact of landuse types and socio-economic factors on the concentration of pollutants in water bodies, but research in this area has been carried out very little.
In summary, studying the impact of land-use types and socio-economic status of the Haikou river system on water quality is of great significance to urban water pollution control decisions. At the same time, it is also necessary to consider the impact of the above indicators on water quality in different hydrological periods. The first part of this study mainly describes the basic situation and data sources of the study area. The main research methods used in the thesis are correlation coefficient analysis, de-trend analysis, and redundancy analysis. The second part analyzes the water quality statistical parameters, spatial distribution characteristics, and the response relationship between water quality and land use and socio-economic indicators in flood and non-flood periods. Through the research of this paper, we will clarify the spatial distribution law of water quality in coastal cities and its relationship with land use types and socio-economic indicators. Provide a decision-making basis for government departments to formulate river governance plans and improve the entire Haikou and Qiongzhou Strait areas' water ecological environment.

\section{Material and Methods}

\section{Study Area}

Haikou City is located at $19^{\circ} 32^{\prime} \sim 20^{\circ} 5^{\prime}$ north latitude and $110^{\circ} 10^{\prime} \sim 110^{\circ} 41^{\prime}$ east longitude. It is located in the northern part of China's Hainan Province, straddling the east and west banks of the Nandu River's lower reaches, with a total area of 2304.84 $\mathrm{km}^{2}$. The geographical location of the study area is shown in Fig. 1. Haikou has gentle terrain, high in the northwest and southeast, low and flat along the Nandu River in the middle, and small coastal plains in the east and northeast. The highest point in the a)

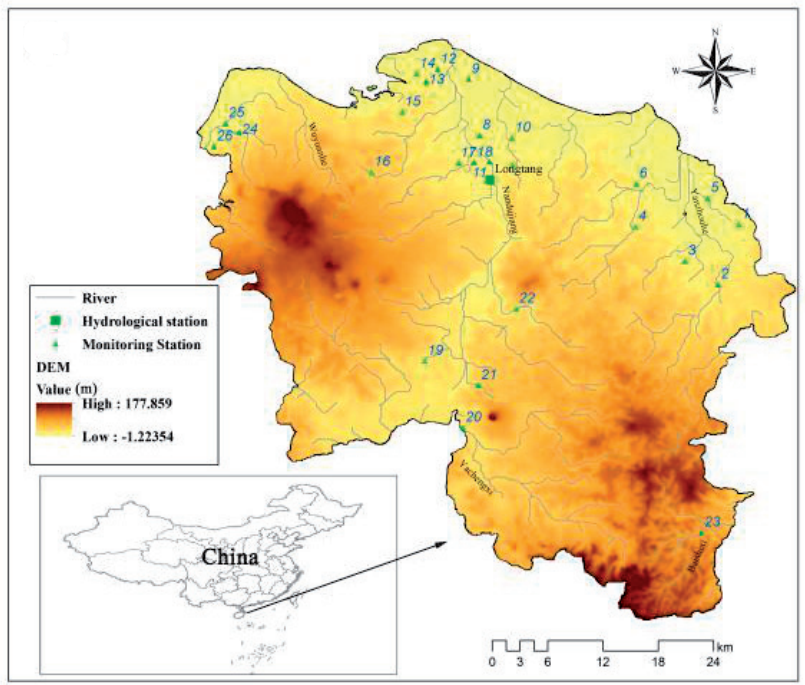

b)

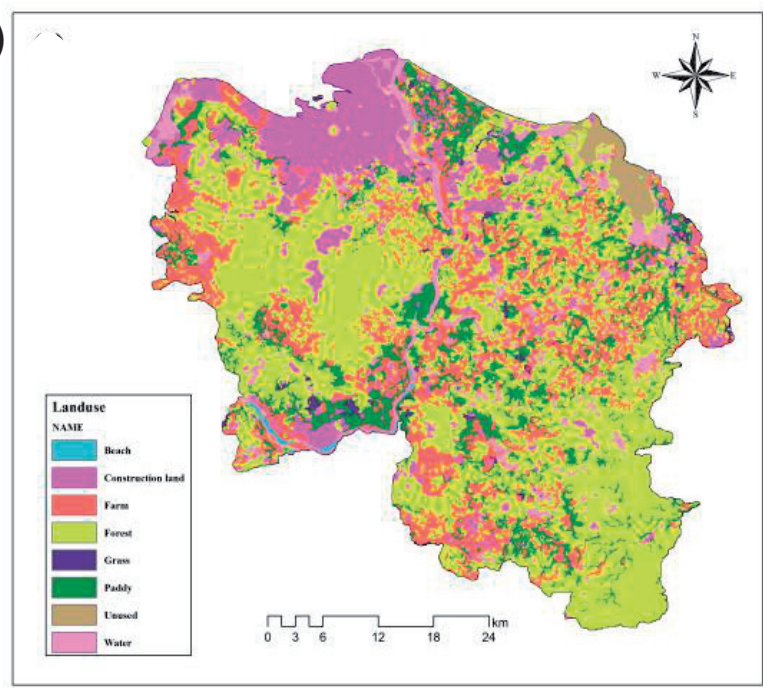

Fig. 1. Location of the study area. 
territory is Ma'anling, with an elevation of $177.86 \mathrm{~m}$, and the lowest point is the Nandu River's open sea mouth with a height of $0.4 \mathrm{~m}$ (Fig. 1a). Haikou has a tropical island climate, and the city's multi-year average precipitation is $1827 \mathrm{~mm}$. May to October is the rainy season, with rainfall accounting for $78.1 \%$ of the annual precipitation; September is the peak period of precipitation, with an average precipitation of $300.7 \mathrm{~mm}$, accounting for $17.8 \%$ of the annual precipitation. The average precipitation in January is only $24 \mathrm{~mm}$. From December to February of the following year, the monthly average precipitation is less than $50 \mathrm{~mm}$; the dry season is from November to April. The precipitation only accounts for $22 \%$ of the whole year. The river network density in the main urban area of Haikou is 0.39 , and the water surface rate is $3.9 \%$.

\section{Data Source}

The water quality data is the measured data of 26 river monitoring sections (Fig. 1b) established by the Haikou Ecological Environment Bureau from 2014 to 2017. Water quality parameters include DO, Permanganate index, $\mathrm{NH}_{3}-\mathrm{N}, \mathrm{TP}, \mathrm{F}$, volatile phenol, and petroleum. The frequency of water quality monitoring is once a month. The water quality standards refer to "Surface Water Environmental Standards" (GB38382002). The water quality parameter standards and testing methods are shown in Table 1.

The $30 \mathrm{~m}$ resolution image data of Landsat 8 in the two phases of July and September 2018 in the study area were selected, and on the basis of geometric correction and atmospheric correction, the land use information in the room was extracted by supervised classification. According to the LUCC classification system established by Liu et a1. [21] in the construction of the "China $20^{\text {th }}$ Century LUCC Spatio-temporal Platform", the land use map of the study area was obtained by interpreting the 7 types of land use among forest land, grassland, paddy field, dry land, water area, construction land, and unused land (Fig. 1b).

\section{Analytical Method}

Use the descriptive statistics function of SPSS 19.0 software to analyze the data sample's structure and overall situation to reflect the actual status behind the data. The comprehensive analysis of the data of water quality elements, the average value, maximum value, minimum value, first quartile (Q1), median, standard deviation, and coefficient of variation obtained can intuitively express the central trend and current status of the Haikou river system's water quality. The coefficient of variation is classified according to the standard of variation grade: $\mathrm{C}_{\mathrm{V}}<10 \%$, weak variability, $10 \% \leq \mathrm{C}_{\mathrm{v}} \leq 100 \%$, medium variability, $\mathrm{C}_{\mathrm{v}}>100 \%$, strong variability. According to Haikou's meteorological conditions, we divided the whole year into two periods: flood season and non-flood season for comparative analysis. The flood season is from May to October (the annual average flow of Longtang Hydrological Station is $\left.84.68 \mathrm{~m}^{3} \cdot \mathrm{s}^{-1}\right)$, and the rest months are non-flood seasons (the annual average flow of Longtang Hydrological Station is $279.55 \mathrm{~m}^{3} \cdot \mathrm{s}^{-1}$ ) Spearman correlation analysis was performed on water quality and land use types in different river system clusters using SPSS190 software. In order to reflect the impact of social economy on water quality, the Canoco4.5 statistical software is used to perform detrend correspondence analysis (DCA) on water quality index data and calculate the gradient length of the sort axis. The Redundancy Analysis Method (RDA) is used to sort and analyze the water quality indicators and socioeconomic data (2016 Haikou Statistical Yearbook) matrix.

\section{Results and Discussion}

\section{Descriptive Statistical Analysis of Water Quality}

The increase of precipitation in the flood season can dilute the concentration of pollutants in the river and increase the scour of the non-point source pollution area

Table 1. Grade concentration values and detection methods of different water quality indicators.

\begin{tabular}{|c|c|c|c|c|c|c|}
\hline \multirow{2}{*}{ Water quality indicators } & \multicolumn{7}{|c|}{ Grade concentration values/ $\left(\mathrm{mg} \cdot \mathrm{L}^{-1}\right)$} & \multirow{2}{*}{ Detection methods } \\
\cline { 2 - 7 } & $\mathrm{I}$ & $\mathrm{II}$ & $\mathrm{III}$ & $\mathrm{IV}$ & $\mathrm{V}$ & Iodometry \\
\hline DO & 7.5 & 6.0 & 5.0 & 3.0 & 2.0 & $\backslash$ \\
\hline Permanganate index & 2.0 & 4.0 & 6.0 & 10.0 & 15.0 & Nessler's reagent colorimetry \\
\hline $\mathrm{NH}_{3}-\mathrm{N}$ & 0.15 & 0.50 & 1.00 & 1.50 & 2.00 & Ammonium Molybdate Spectrophotometry \\
\hline $\mathrm{TP}$ & 0.02 & 0.1 & 0.2 & 0.3 & 0.4 & Ion selective electrode method \\
\hline $\mathrm{F}$ & 1.0 & 1.0 & 1.0 & 1.5 & 1.5 & 4-aminoantipyrine spectrophotometer after \\
\hline Volatile Phenol & 0.002 & 0.002 & 0.005 & 0.01 & 0.1 & Infrared spectrophotometry \\
\hline Petroleum & 0.05 & 0.05 & 0.05 & 0.5 & 1.0 & \\
\hline
\end{tabular}


so that more pollutants will be collected in the river. Therefore, the water quality of rivers in different places responds differently to precipitation. The statistical analysis of the river system's water quality parameters in Haikou City is shown in Table 2.

The mean values of DO in the flood season and non-flood season are $4.18 \mathrm{mg} \cdot \mathrm{L}^{-1}$ and $4.86 \mathrm{mg} \cdot \mathrm{L}^{-1}$, respectively, reaching surface water quality Class IV. This may be related to the high precipitation in Haikou, the large annual runoff of the river, and sufficient water flow. The average concentration of $\mathrm{NH}_{3}-\mathrm{N}$ in nonflood season (4.44 $\left.\mathrm{mg} \cdot \mathrm{L}^{-1}\right)$ exceeds the water quality standard of Class $\mathrm{V}$, and the median is $0.47 \mathrm{mg} \cdot \mathrm{L}^{-1}$, the first quartile is $0.16 \mathrm{mg} \cdot \mathrm{L}^{-1}$, with a maximum value of $25.30 \mathrm{mg} \cdot \mathrm{L}^{-1}$. The average is much larger than the median, which indicates that the maximum value has a more significant impact on this indicator. The variation coefficient is $177 \%$, a strong variation with significant spatial differences; the mean value in flood season $\left(2.18 \mathrm{mg} \cdot \mathrm{L}^{-1}\right)$ is relatively low, close to the water quality standard of Class $\mathrm{V}$, and the coefficient of variation is also high. There was little difference in the average concentration of TP in the two periods, which were $0.49 \mathrm{mg} \cdot \mathrm{L}^{-1}$ and $0.47 \mathrm{mg} \cdot \mathrm{L}^{-1}$, respectively, which were higher than the water quality standard of Class $\mathrm{V}$. The coefficients of variation are all high, belonging to strong variation, with significant spatial differences. The average values of F, Volatile phenol, and Petroleum in the two periods can reach the water quality Class I. However, the maximum values of volatile phenols and Petroleum in non-flood season went $0.035 \mathrm{mg} \cdot \mathrm{L}^{-1}$ and $0.27 \mathrm{mg} \cdot \mathrm{L}^{-1}$, respectively, which belonged to the water quality standard of Class IV. The coefficient of variation of Petroleum in the non-flood season is $231 \%$, which is higher than all other indicators and is a strong variation with significant spatial differences. Pollutants in Haikou's rivers are mainly nitrogen and phosphorus pollution, while organic pollution such as volatile phenol and Petroleum is relatively small.

\section{Spatial Distribution Characteristics of Water Quality}

According to the "Haikou City River system Planning," referring to the river's attributes and location, we divided the city into 4 river system clusters H1-H4.

Fig. 2 shows the spatial distribution of water quality indicators during non-flood seasons (left column) and flood seasons (right column). Table 2 shows the average, maximum and minimum values of the leading water quality indicators during the flood season and non-flood season in the H1-H4 region. The analysis results show that, except for some areas of Petroleum, which have increased during the flood season, all other indicators show the characteristics of decreasing during the flood season. This may be due to the low rainfall during the non-flood season, which reduces pollutants' dilution in coastal industrial point sources, farmland, livestock and poultry breeding, and urban domestic sewage [22]. During the flood season, precipitation has diluted the N, P, and other nutrients, organic pollutants, and soluble pollutants that scoured from the surface into the river, resulting in lower concentrations. This shows that water volume is an essential driving force for the improvement of water quality in Haikou. External pollution input is the main cause of water pollution.

Table 2. Statistical characteristics of water quality of Haikou river system.

\begin{tabular}{|c|c|c|c|c|c|c|c|c|}
\hline Period & $\begin{array}{l}\text { Statistical } \\
\text { Parameters }\end{array}$ & $\begin{array}{c}\mathrm{DO} / \\
\left(\mathrm{mg} \cdot \mathrm{L}^{-1}\right)\end{array}$ & $\begin{array}{l}\text { Permanganate } \\
\text { Index } /\left(\mathrm{mg} \cdot \mathrm{L}^{-1}\right)\end{array}$ & $\begin{array}{l}\mathrm{NH}_{3}-\mathrm{N} / \\
\left(\mathrm{mg} \cdot \mathrm{L}^{-1}\right)\end{array}$ & $\begin{array}{c}\mathrm{TP} / \\
\left(\mathrm{mg} \cdot \mathrm{L}^{-1}\right)\end{array}$ & $\begin{array}{c}\mathrm{F} / \\
\left(\mathrm{mg} \cdot \mathrm{L}^{-1}\right)\end{array}$ & $\begin{array}{l}\text { Volatile Phenol / } \\
\qquad\left(\mathrm{mg} \cdot \mathrm{L}^{-1}\right)\end{array}$ & $\begin{array}{l}\text { Petroleum / } \\
\left(\mathrm{mg} \cdot \mathrm{L}^{-1}\right)\end{array}$ \\
\hline \multirow{7}{*}{$\begin{array}{l}\text { Non-flood } \\
\text { season }\end{array}$} & Max & 11.20 & 36.80 & 25.30 & 5.45 & 0.70 & 0.0090 & 0.39 \\
\hline & Min & 0.30 & 0.70 & 0.01 & 0.03 & 0.03 & 0.0002 & 0.01 \\
\hline & AVG & 4.86 & 6.01 & 2.50 & 0.49 & 0.18 & 0.0009 & 0.02 \\
\hline & Q1 & 3.03 & 3.20 & 0.16 & 0.11 & 0.10 & 0.0002 & 0.005 \\
\hline & $\mathrm{Me}$ & 5.05 & 4.40 & 0.47 & 0.20 & 0.15 & 0.0003 & 0.005 \\
\hline & Stdev & 2.50 & 4.71 & 4.44 & 0.76 & 0.12 & 0.0013 & 0.04 \\
\hline & $\mathrm{Cv}(\%)$ & 51 & 78 & 177 & 156 & 69 & 149 & 231 \\
\hline \multirow{7}{*}{$\begin{array}{l}\text { Flood } \\
\text { season }\end{array}$} & Max & 11.60 & 23.50 & 18.70 & 4.15 & 0.900 & 0.0350 & 0.27 \\
\hline & Min & 0.10 & 0.90 & 0.01 & 0.03 & 0.060 & 0.0002 & 0.00 \\
\hline & AVG & 4.18 & 5.76 & 2.18 & 0.47 & 0.226 & 0.0008 & 0.02 \\
\hline & Q1 & 2.10 & 3.40 & 0.10 & 0.11 & 0.15 & 0.00015 & 0.005 \\
\hline & $\mathrm{Me}$ & 4.20 & 4.75 & 0.41 & 0.24 & 0.20 & 0.00015 & 0.005 \\
\hline & Stdev & 2.47 & 3.36 & 3.65 & 0.62 & 0.113 & 0.0033 & 0.03 \\
\hline & $\mathrm{Cv}(\%)$ & 59 & 58 & 168 & 131 & 50 & 226 & 207 \\
\hline
\end{tabular}



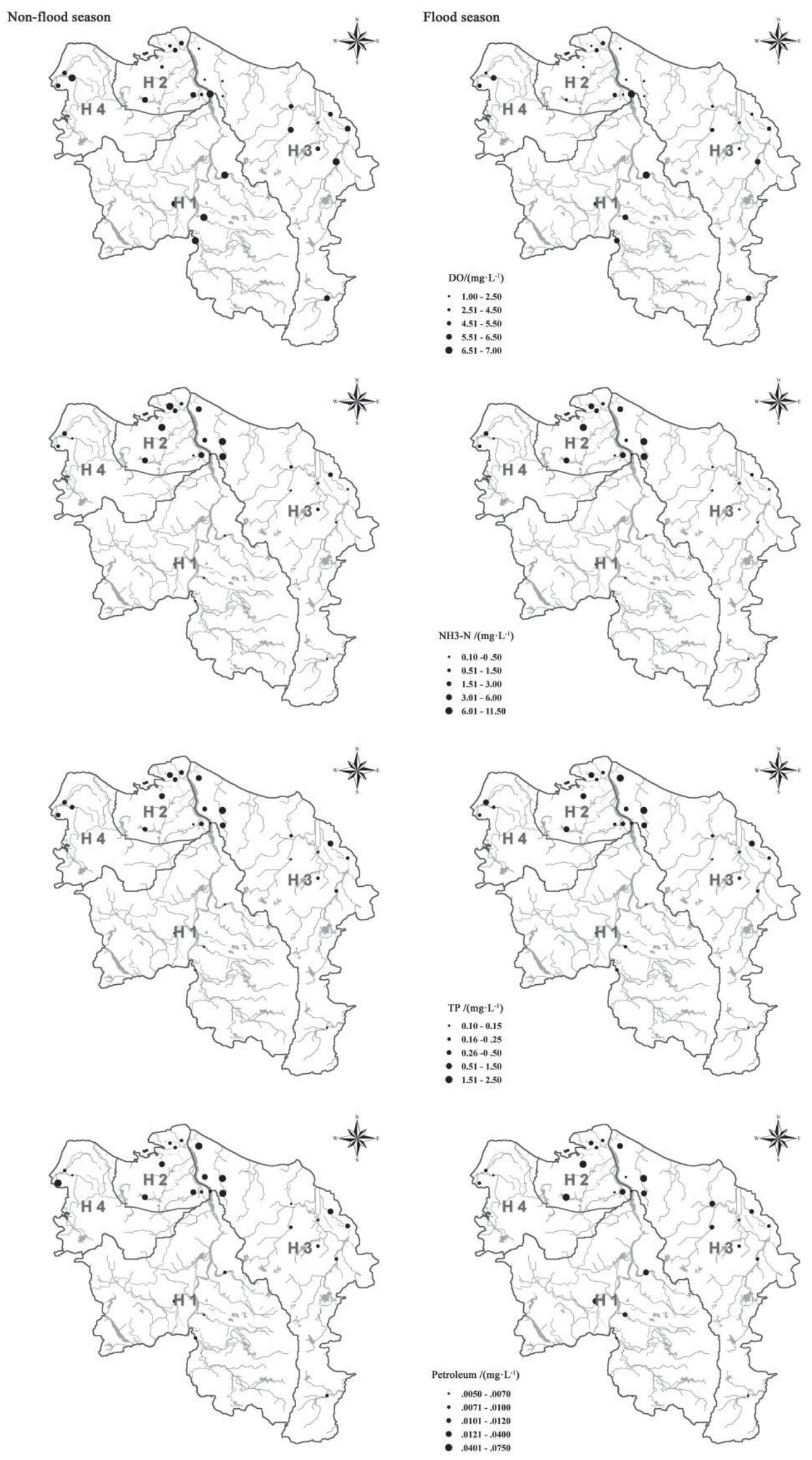

Fig. 2. Spatial distribution of water quality indicators in Haikou. 
Table 3. Mean value, maximum value and minimum value of different water quality indicators in $\mathrm{H} 1-\mathrm{H} 4$ area during flood season and non-flood season.

\begin{tabular}{|c|c|c|c|c|c|c|c|c|c|c|c|c|c|}
\hline \multirow{2}{*}{ Period } & \multirow{2}{*}{$\begin{array}{l}\text { River system } \\
\text { cluster }\end{array}$} & \multicolumn{3}{|c|}{$\mathrm{DO} /\left(\mathrm{mg} \cdot \mathrm{L}^{-1}\right)$} & \multicolumn{3}{|c|}{$\mathrm{NH}_{3}-\mathrm{N} /\left(\mathrm{mg} \cdot \mathrm{L}^{-1}\right)$} & \multicolumn{3}{|c|}{$\mathrm{TP} /\left(\mathrm{mg} \cdot \mathrm{L}^{-1}\right)$} & \multicolumn{3}{|c|}{ Petroleum $/\left(\mathrm{mg} \cdot \mathrm{L}^{-1}\right)$} \\
\hline & & Max & Min & AVG & Max & Min & AVG & Max & Min & AVG & Max & Min & AVG \\
\hline \multirow{4}{*}{$\begin{array}{l}\text { Non-flood } \\
\text { season }\end{array}$} & H1 & 6.88 & 6.16 & 6.67 & 0.28 & 0.12 & 0.18 & 0.14 & 0.10 & 0.12 & 0.01 & 0.01 & 0.01 \\
\hline & $\mathrm{H} 2$ & 6.04 & 2.67 & 4.29 & 8.45 & 0.15 & 4.02 & 1.28 & 0.11 & 0.56 & 0.02 & 0.01 & 0.01 \\
\hline & H3 & 6.70 & 1.33 & 4.13 & 11.10 & 0.19 & 2.98 & 2.38 & 0.12 & 0.66 & 0.07 & 0.01 & 0.03 \\
\hline & H4 & 6.70 & 4.90 & 5.51 & 2.12 & 0.40 & 1.23 & 0.46 & 0.27 & 0.36 & 0.08 & 0.01 & 0.03 \\
\hline \multirow{4}{*}{ Flood season } & $\mathrm{H} 1$ & 6.82 & 5.27 & 6.17 & 0.31 & 0.08 & 0.17 & 0.20 & 0.11 & 0.15 & 0.02 & 0.01 & 0.01 \\
\hline & $\mathrm{H} 2$ & 5.32 & 1.57 & 3.34 & 10.08 & 0.22 & 4.00 & 1.21 & 0.18 & 0.60 & 0.06 & 0.01 & 0.02 \\
\hline & $\mathrm{H} 3$ & 6.09 & 1.29 & 3.68 & 9.53 & 0.09 & 2.18 & 1.85 & 0.06 & 0.56 & 0.04 & 0.01 & 0.02 \\
\hline & $\mathrm{H} 4$ & 6.18 & 3.19 & 4.64 & 2.63 & 0.15 & 1.26 & 0.65 & 0.17 & 0.35 & 0.01 & 0.01 & 0.01 \\
\hline
\end{tabular}

From the perspective of spatial distribution, there are significant differences between the river system clusters. The overall water quality shows a trend of deterioration from the southern inland area to the northern coastal area. As can be seen from Table 3, the H1 river system cluster is mainly located in Haikou's inland area, with relatively few pollution sources. The average values of DO and petroleum in the two periods can reach water quality standard $\mathrm{I}, \mathrm{NH}_{3}-\mathrm{N}$ can reach water quality standard II or higher, and TP can reach water quality standard III or higher. And the concentration difference of each site is not significant. Simultaneously, for DO, $\mathrm{NH}_{3}-\mathrm{N}$, and $\mathrm{TP}$, regardless of the average value or the maximum value, the $\mathrm{H} 2$ water system group has the worst performance in the 4 regions. This may be due to the $\mathrm{H} 2$ river system cluster is mainly located in Haikou's central urban area, which is the primary production and living area. Human activities are the most intensive, and the estuary of many rivers is located in this area, which is the most downstream. Due to the cumulative effect of upstream pollutants, the water quality is generally low. Among them, $\mathrm{NH}_{3}-\mathrm{N}$ and TP are the worst indicators, and the average concentration of both during the flood season and the non-flood season is higher than the water quality class V. Most of the rivers in this area are tidal sections, and the exchange of water bodies is relatively sufficient. DO can reach surface water above the water quality class III, and petroleum is the best, which can meet the water quality class I. Due to the direct exchange between the area and the ocean water body, the site should focus on pollutant control. In the $\mathrm{H} 3$ river system cluster, the spatial difference of each station is noticeable. The overall performance is that the inland area's pollution is relatively good, and the water quality near the river estuary in the west and north is low. The H4 river system cluster has relatively few monitoring sites, and petroleum is the weakest among all clusters. The average DO concentration in the two periods has reached the water quality class II.

\section{The Response Relationship between Land Use and Water Quality}

It can be seen from Fig. 3 that the land use in Haikou is dominated by forest land, accounting for $50.62 \%$ of the city's total area, and beach land accounting for the smallest proportion, only $0.25 \%$. In terms of river system clusters, the three river system clusters H1, H3, and $\mathrm{H} 4$ have the largest forest area ratio, accounting for about $53.1 \%$ to $54.5 \%$. The farmland is followed, and these three clusters account for $17.9 \% \sim 21.4 \%$, respectively. $\mathrm{H} 2$ river system cluster is mainly based on construction land, accounting for more than $68 \%$ of the region's total area.

The correlation analysis between the proportion of land use types and water quality indicators in the flood and non-flood periods in the study area is shown in Table 4. The results show that in the non-flood season, DO is negatively correlated with the water body area. This is mainly due to the decrease of rainfall and the slowing of the water flow rate, which reduces the dynamic effect of oxygen into the water body, which causes the reduction of the water body DO concentration. $\mathrm{NH}_{3}-\mathrm{N}$ exhibits a negative correlation with farm and forest land, which is consistent with the research conclusion of Sun et al. [23] on the Dianchi Lake Basin. The study of Tu et al. [24] showed that this negative correlation could not be used to reversely indicate that the increase and decrease of agricultural land inhibited $\mathrm{NH}_{3}-\mathrm{N}$ pollution. This may be because the main factors causing river nitrogen pollution occur with spatial location. The rapid increase in impervious area in urban areas and the increase in point source pollution have led to an increase in the concentration of $\mathrm{NH}_{3}-\mathrm{N}$. Changes in the concentration of nitrogen pollutants are greatly affected by changes in the proportion of forest land because forests can effectively control the concentration of pollutants in water bodies. River pollution is an ecological process that occurs with the exchange and migration of materials and energy in 


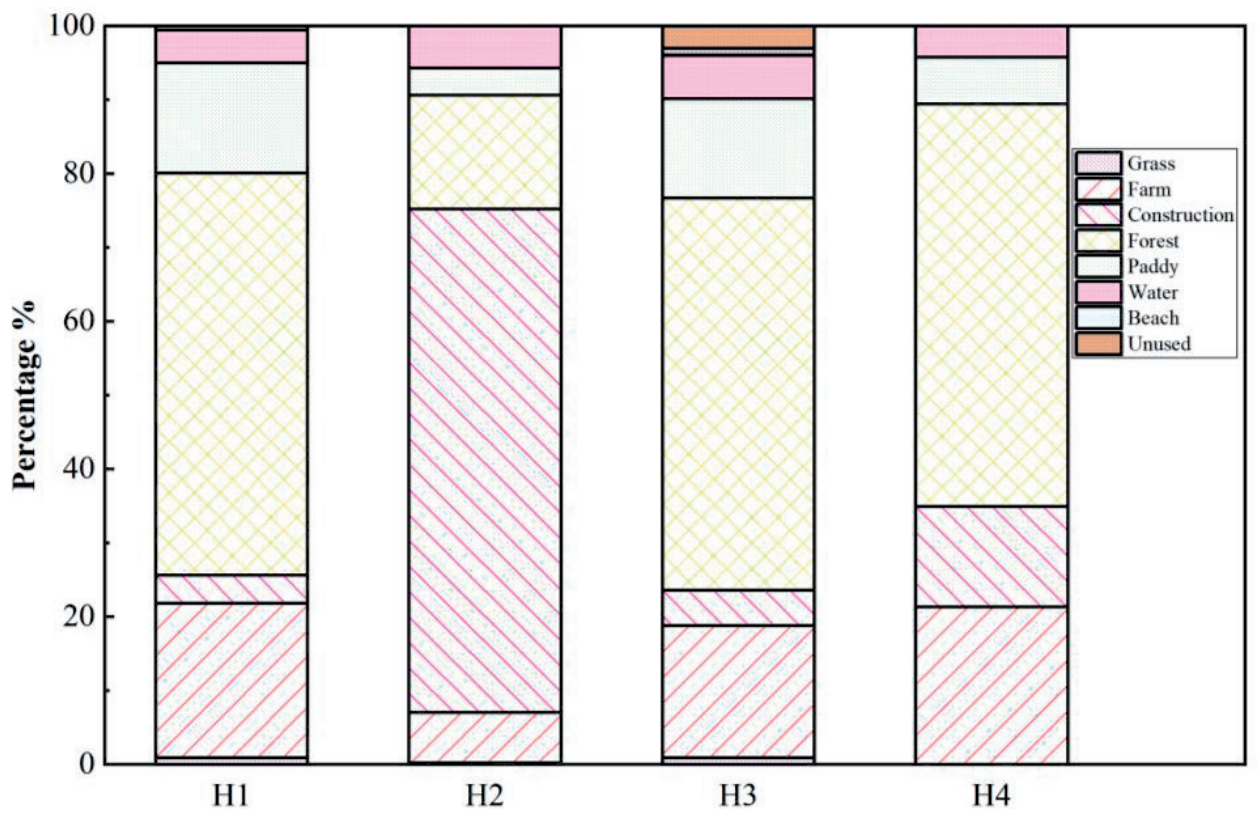

Fig. 3. River system cluster land use type area ratio.

the ecosystem, hydrological processes, and soil erosion [25]. Under the action of forest vegetation, it can effectively prevent soil erosion, reduce the degree of soil erosion caused by rainfall-runoff, and show apparent interception, filtration, absorption, and transformation of pollutants [26-27]. There is a positive correlation between TP and water area, which may be mainly concentrated in the upstream region. The upper reaches" economy is dominated by agricultural production, which increases external phosphorus input, and pollutants migrate into the water area along with runoff. F shows a negative correlation with grassland and paddy field and a positive correlation with construction land. Volatile phenol is positively correlated with construction land and negatively correlated with beaches. Because these indicators are low in content and not representative, no specific analysis will be done.

Table 4. Spearman correlation analysis between water quality and land use.

\begin{tabular}{|c|c|c|c|c|c|c|c|c|}
\hline Period & Landuse types & DO & Permanganate Index & $\mathrm{NH}_{3}-\mathrm{N}$ & $\mathrm{TP}$ & $\mathrm{F}$ & Volatile Phenol & Petroleum \\
\hline \multirow{8}{*}{$\begin{array}{l}\text { Non-flood } \\
\text { season }\end{array}$} & Grass & 0.1 & -0.3 & -0.3 & -0.1 & -0.9 & -0.8 & -0.6 \\
\hline & Farm & 0.8 & -0.4 & 0.9 & -0.8 & -0.3 & -0.4 & 0.3 \\
\hline & Construction & -0.3 & 0.6 & 0.6 & 0.3 & 1.0 & 0.9 & 0.3 \\
\hline & Forest & 0.7 & -0.4 & -0.9 & -0.7 & -0.7 & -0.6 & 0 \\
\hline & Paddy & 0.3 & -0.6 & -0.6 & -0.3 & -1.0 & -0.9 & -0.3 \\
\hline & Water & -0.9 & 0.8 & 0.8 & 0.9 & 0 & 0.2 & -0.1 \\
\hline & Beach & 0.3 & -0.4 & -0.4 & -0.3 & -0.8 & -0.9 & -0.7 \\
\hline & Unused & -0.7 & 0.3 & 0.3 & 0.7 & -0.3 & -0.2 & 0.3 \\
\hline \multirow{8}{*}{ Flood season } & Grass & -0.3 & 0.1 & 0.3 & 0.1 & 0.8 & 0.7 & 1 \\
\hline & Farm & -0.9 & 0.8 & 0.9 & 0.8 & 0.1 & 0.5 & 0.6 \\
\hline & Construction & 0.6 & -0.3 & -0.6 & -0.3 & -0.9 & -0.9 & -0.1 \\
\hline & Forest & 0.9 & -0.7 & -0.9 & -0.7 & -0.5 & -0.9 & -0.6 \\
\hline & Paddy & 0.6 & -0.3 & -0.6 & -0.3 & -0.9 & -0.9 & -0.1 \\
\hline & Water & -0.8 & 0.8 & 0.8 & 0.9 & -0.3 & 0.2 & 0.8 \\
\hline & Beach & 0.4 & -0.3 & -0.4 & -0.3 & -0.6 & -0.5 & -0.1 \\
\hline & Unused & -0.3 & 0.7 & 0.3 & 0.7 & -0.7 & -0.1 & 0.9 \\
\hline
\end{tabular}


During the flood season, DO shows a negative correlation with farmland and a positive correlation with forest land. It shows that the non-point source pollution caused by agricultural land causes the increase of water body oxygen consumption and the slowdown of water body flow rate, which leads to the decrease of water body dissolved oxygen content. The water conservation effect of forest land makes the pollutant content of regional water bodies less and less oxygen. $\mathrm{NH}_{3}-\mathrm{N}$ showed a positive correlation with agricultural land and a negative correlation with forest land. It indicates that agricultural activities in the flood season are the main driving factors for water bodies" eutrophication. Residual fertilizers, pesticides, and pesticides in agricultural land will enter the water body under the rain. Forest land can intercept pollution by delaying surface runoff. There is a positive correlation between TP and water area, and the reason is the same as that of the non-flood season. F shows a negative correlation with paddy fields and a positive correlation with construction land. Volatile phenol has a negative correlation with construction land, woodland and paddy field. Petroleum shows a positive correlation with unused land, which is not very representative and will not be analyzed.

\section{The Response Relationship between Social Economy and Water Quality}

This study uses the districts and counties of Haikou City as the statistical unit and selects the population density (PD), per capita GDP (GDP/ capita), the proportion of the primary industry in the GDP (PPI), the proportion of secondary industry in GDP (PSI) and the proportion of tertiary industry in GDP (PTI) are social and economic indicators that affect the quality of the water environment in the basin. Through the spatial analysis tool of ArcGIS 10.2, according to the area weight assigned to each river system group, and then analyze the correlation between social economy and water quality.

From the RDA results in Fig. 4, it can be seen that TP, Permanganate index, Petroleum, and volatile phenols are significantly positively correlated with PTI during non-flood season. This is mainly due to the agglomeration of the catering industry and commerce, which makes the area prone to excessive sewage discharge, especially in the economically underdeveloped river basin, where the sewage treatment system is imperfect, which causes the increase in the concentration of TP and organic pollutants in the water body. There is a negative correlation with PPI and PSI, which may be due to the decrease of precipitation in non-flood seasons, which weakened the migration of phosphorus with surface runoff to some extent. Industrial point source pollution accounts for a relatively small proportion of water pollution in Haikou. $\mathrm{F}$ and $\mathrm{NH}_{3}-\mathrm{N}$ are positively correlated with GDP/ capita and $\mathrm{PD}$ and negatively correlated with DO This is mainly due to intensive man-made and economic activities, such as the direct discharge of domestic sewage, which caused direct pollution of nitrogen in the water body, and at the same time aggravated the activity of oxygenconsuming microorganisms in the water body and reduced the DO content in the water body. This result also validates the previous research results of $\mathrm{Tu}$ et al. [28] and Liu et a1. [29].

During the flood season, DO, Permanganate index, and petroleum has a certain degree of positive correlation with PSI and a negative correlation with PD. This may be due to the precipitation in the flood season that caused some industrial wastewater to enter the water body without the pipe network, causing a certain degree of organic pollution. Residents' domestic a)

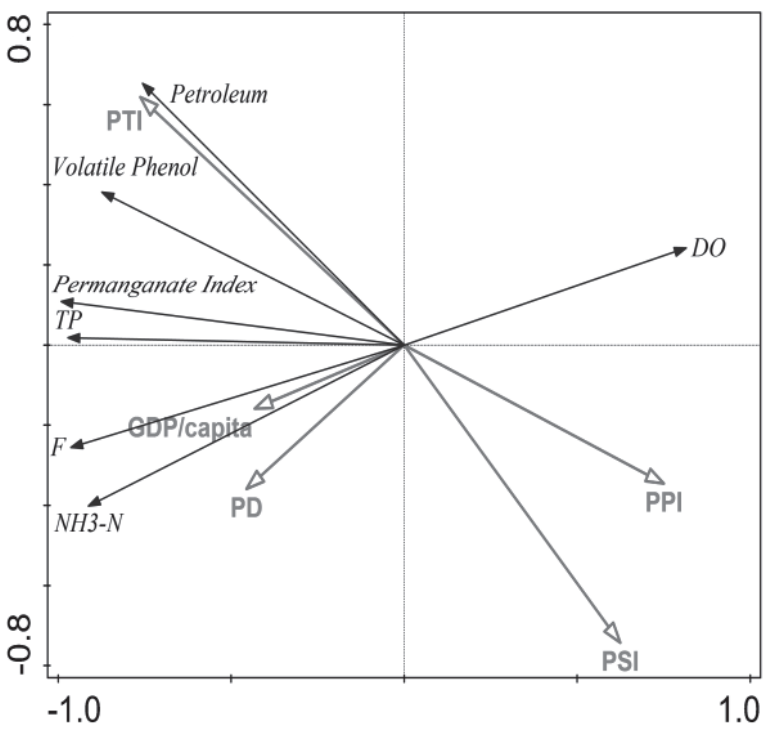

b)

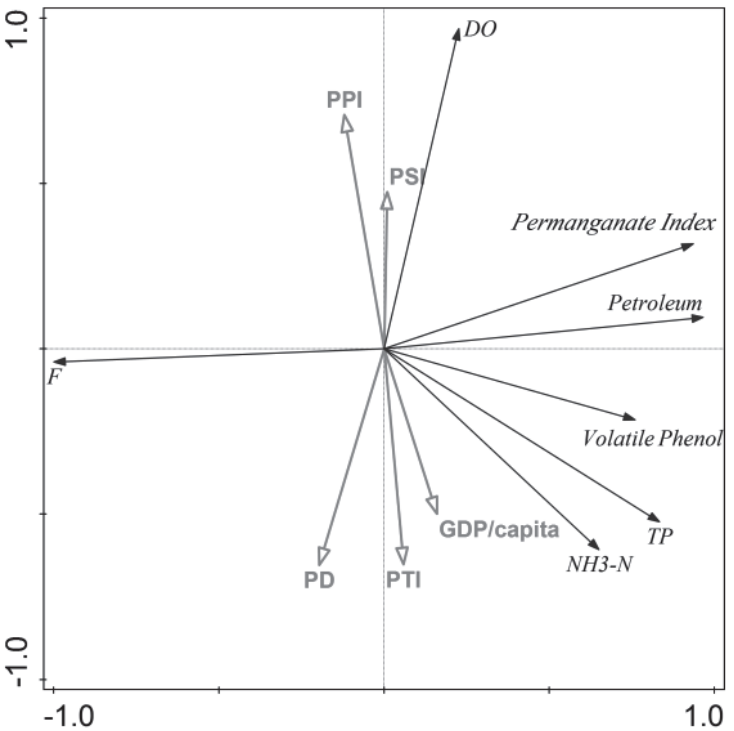

Fig. 4. RDA ranking map of water quality indicators and basin socio-economics a) Non-flood season, b) Flood season. 
sewage contributes little to the Permanganate index and petroleum. $\mathrm{NH}_{3}-\mathrm{N}, \mathrm{TP}$, and volatile phenols are significantly positively correlated with GDP/capita and PTI and significantly negatively correlated with PPI. The reason for this result is that the economic development level of each river system group is large. With the increase of GDP, the population is concentrated, and the proportion of the industrial structure's primary industry decreases. This is different from the areas where agriculture is the pillar industry [30]. Studies have also pointed out that due to a large amount of organic phosphorus and organic nitrogen in the domestic sewage of urban residents, the water body's $\mathrm{N}$ and $\mathrm{P}$ contents are higher after being discharged into the river $[16,31]$.

\section{Conclusions}

1) The water quality of the Haikou river system is generally poor. Water pollution in non-flood seasons is more severe than in flood seasons. The eutrophic pollution of $\mathrm{NH}_{3}-\mathrm{N}$ and TP. is strict, and the emission of external pollution far exceeds the dilution effect of precipitation. From the perspective of spatial distribution, the water pollution in the entire Haikou area shows a trend of increasing from inland to near the sea entrance. The $\mathrm{H} 1$ river system cluster has the least pollution, and the $\mathrm{H} 2-\mathrm{H} 3$ river system cluster is more serious, whether it is organic or inorganic pollutants. In particular, the $\mathrm{H} 2$ river system group is a key area for water pollution prevention and control.

2) From the perspective of the correlation between land use and water quality, the correlation between $\mathrm{N}$, $\mathrm{P}$ and agricultural land in the Haikou area is weak, and non-flood season farmland non-point source pollution is not the main channel of water pollution in Haikou. Forest land plays a perfect role in intercepting pollutants, conserving water sources, and purifying water quality.

3) $\mathrm{N}$ and P pollutants are greatly affected by urban residents ${ }^{\star}$ activities and tertiary industry activities. Pollutants in water bodies mainly come from the discharge of domestic and industrial sources. Organic pollutants are also affected by pollution, as mentioned earlier, emissions. DO. is primarily influenced by population density.

\section{Acknowledgements}

The authors express their gratitude for the support provided by Haikou Environmental Protection Bureau.

\section{Conflict of Interest}

The authors declare no conflict of interest.

\section{References}

1. XIAO W. Management of agricultural nonpoint source pollution in China: current status and challenges. Water Science Technology. 53 (2), 1, 2006.

2. BU H., WAN, J., ZHANG Y., MENG W. Spatial characteristics of surface water quality in the Haicheng River (Liao River basin) in Northeast China. Environmental Earth Sciences. 70 (6), 2865, 2013.

3. ROTHENBERGER M.B., BURKHOLDER J.A., M.BROWNIE C. Long-Term Effects of Changing Land Use Practices on Surface Water Quality in a Coastal River and Lagoonal Estuary. Environmental Management. 44 (3), 505, 2009.

4. WEI S., SHOUBEN Z., JIANSEN Y., XIAO W., JINLONG Z., YUANJIN L. Quality assessment of aquatic environment and fluxes of major pollutants to the Xiaoqing River estuary. Marine Environmental Science. 36 (3), 366, 2017.

5. WALSH C.J., WEBB J.A. Spatial weighting of land use and temporal weighting of antecedent discharge improves prediction of stream condition. Landscape Ecology. 29 (7), 1171, 2014.

6. FAN Z.P., LIU J.Z., ZHAO Y., WANG Q., LI F., TU Z.H. Spatial heterogeneity of water quality and its response to land use in Puhe River Basin. Chinese Journal of Ecology. 037 (004), 1144, 2018 [In Chinese].

7. RUIZHAO W., TIANLE X., LIZHONG Y., JIAOJUN Z., XIAOYU L. Effects of land use types on surface water quality across an anthropogenic disturbance gradient in the upper reach of the Hun River, Northeast China. Environmental Monitoring Assessment. 185 (5), 4141, 2013.

8. YANG C.H., SU Q., CHEN Z.H., BAI J.W., QIAN X.Q., ZHANG Z.M. Correlation Between LDI-based Land Use Types and Water Quality in Sanshan Island of Taihu Lake National Wetland Park,Suzhou. Environmental Science. 38 (01), 106, 2017 [In Chinese].

9. WANG Q., WANG S.X., FAN Z.P., LI F.Y. Impacts of land use and socioeconomic activity on spatial variation of water quality in upper area of Dahuofang Reservoir. Ecological Science. 37 (02), 153, 2018 [In Chinese].

10. POUDEL D.D., LEE T., SRINIVASAN R., ABBASPOUR K., JEONG C.Y. Assessment of seasonal and spatial variation of surface water quality, identification of factors associated with water quality variability, and the modeling of critical nonpoint source pollution areas in an agricultural watershed. Journal of Soil Water Conservation. 68 (3), 155, 2013.

11. MENARIVERA L., SALGADOSILVA V., BENAVIDESBENAVIDES C., COTOCAMPOS J., SWINSCOE T. Spatial and Seasonal Surface Water Quality Assessment in a Tropical Urban Catchment: Burío River, Costa Rica. Water. 9 (8), 558, 2017.

12. SINGH K.P., MALIK A., MOHAN D., SINHA S. Multivariate statistical techniques for the evaluation of spatial and temporal variations in water quality of Gomti River (India) - a case study - ScienceDirect. Water Research. 38 (18), 3980, 2004.

13. BENGRANE K., MARHABA T.F. Using principal component analysis to monitor spatial and temporal changes in water quality. Journal of Hazardous Materials. 100 (1-3), 179, 2003.

14. TANG Y.L., XIANG Y.X., FENG T.T., SUN J., TAO J.L., FU J.X. Spatial and temporal specific features of the water 
quality of Shenyang-Fushun basin of Hunhe River through a multivuariate statistical analysis. Journal of Safety and Environment. (5), 2018 [In Chinese].

15. ZHU L., WANG Y.N., HAN M., ZHU Y.Z., YU H.B., SONG, Y.H. Spatio-temporal distribution of water quality and source identification of pollution in Wushui River Basin. Journal of Environmental Sciences. 38 (006), 2150, 2018 [In Chinese].

16. AHEARN D.S., SHEIBLEY R.W., DAHLGREN R.A., ANDERSON M., JOHNSON J., TATE K.W. Land use and land cover influence on water quality in the last free-flowing river draining the western Sierra Nevada, California. Journal of Hydrology. 313 (3), 234, 2005.

17. TRAN C.P., BODE R.W., SMITH A.J., KLEPPEL G.S. Land-use proximity as a basis for assessing stream water quality in New York State (USA). Ecological Indicators. 10 (3), 727, 2010

18. NIKANOROV A.M. National monitoring of land surface water pollution and perspectives of its development. Russian Meteorology Hydrology. 35 (1), 20, 2010.

19. KAVITA S., PRASHANT K.S., IPSITA N., NIDHI S. Water sustainability: reforming water management in new global era of climate change. Environmental Science Pollution Research. 21, 11603, 2014.

20. DU X., XU D., FU X., WU G. An empirical research on the relationship between water environment and economic development in liaohe river watershed. Acta Ecologica Sinica. 35 (6), 1955, 2015 [In Chinese].

21. LIU J.Y., ZHUANG D.F., ZHANG Z.X., GAO Z.Q., DENG X.Z. The Establishment of Land-use Spatialtemporal Database and Its Relative Studies in China. Geoinformation Science. (2), 2002 [In Chinese].

22. SEO Y., SCHMIDT A.R. The effect of rainstorm movement on urban drainage network runoff hydrographs. Hydrological Processes. 26 (25), 3830, 2012.

23. SUN J.H., CAO X.F., HUANG Y. Effect of land use on inflow rivers water quality in lake Dianchi watershed.
China Environmental Science. 31 (12), 2052, 2011 [In Chinese].

24. TU J. Spatial Variations in the Relationships between Land Use and Water Quality across an Urbanization Gradient in the Watersheds of Northern Georgia, USA. Environmental Management. 51 (1), 1, 2013.

25. YU L., YI-HE L., BO-JIE F. Implication and limitation of land-scape metrics in delineating relationship between landscape pattern and soil erosion. Acta Ecologica Sinica. 31 (01), 267, 2011 [In Chinese].

26. ZHAO O., XIA B.C., QIN J.Q., ZHAO H.R. Multivariate correlation analysis between landscape pattern and water quality. Acta Ecologica Sinica. 32 (008), 2331, 2012 [In Chinese].

27. SHAN N., RUAN X., XU J., PAN Z. Estimating the optimal width of buffer strip for nonpoint source pollution control in the Three Gorges Reservoir Area, China. Ecological Modelling. 276, 51, 2014.

28. TU J. Spatially varying relationships between land use and water quality across an urbanization gradient explored by geographically weighted regression. Applied Geography. 31 (1), 376, 2011.

29. LIU Z., WANG Y., LI Z., PENG J. Impervious surface impact on water quality in the process of rapid urbanization in Shenzhen, China. Environmental Earth Sciences. 68 (8), $2365,2013$.

30. JIAO W., KEMING M., YUXIN Z., RONGLI T. Impacts of land use and socioeconomic activity on river water quality. Acta Scientiae Circumstantiae. 032 (1), 57, 2012 [In Chinese].

31. XIAO H., JI, W. Relating landscape characteristics to nonpoint source pollution in mine waste-located watersheds using geospatial techniques. Journal of Environmental Management. 82 (1), 111, 2007. 